\title{
Liberating Education: The Dissident Voice of a Good Enough School
}

\author{
Martha Paiva Scardua \\ Universidade Católica de Brasília \\ martha.scardua@gmail.com \\ Afonso Galvão \\ Universidade Católica de Brasília \\ acetaga@gmail.com
}

\begin{abstract}
This study develops a concept of the Good Enough School inspired by Freire's (1997) Liberating Education and Dussel's (1977) Philosophy of Liberation in response to policies and practices that reduce the focus of education to a mere performance on national and international tests, and the search for first places on rankings. We criticize educational models that minimize important educational dimensions, such as qualification (learning of formal knowledge), humanization, democratization and transcendentalism, that are essential to the construction of another model of social and economic development. The Good Enough School is based on the ethics of otherness and assumes the importance of decolonization processes in the ways of being, thinking and acting. It is oriented towards dealing with personal, social, local and global challenges through potential spaces (Winnicott, 1975) that ensure the care of children and young people who were not socialized in a good enough environment, and spaces of appearance (Arendt, 2007), which ensure the political exercise of citizenship and democracy to the school community.
\end{abstract}

\section{Introduction}

School inequality in Brazil has decreased in the last years, but it still constitutes an obstacle to sustainable development and equality promotion. The implementation of neoliberal educational policy in Brazil, from the 1990s onwards, has intensified the processes of assessment, comparison and competition amongst schools, teaching systems and nations in a strong scenario of governance where pedagogical tendencies of religious, humanist, democratic and liberal/neoliberal types are mixed up.

The centrality of neoliberal policies in the educational field is influenced by a type of globalization guided by a philosophy whose ontology has placed the dominant, Western white male as the epicentre of the world (Dussel, 1977). According to the reasoning of this philosophy, the metanarrative of modernity has been the stage of contradictions concerning promises of happiness and social well-being. From the point of view of the school institution, for example, it can be observed that its pedagogical and management practices have de-humanised relationships and the pedagogical work itself, phenomenon that can be observed in the malaise of the teaching profession and in the emergence of alternative experiences of school organization.

Particularly, schools have been engaged in the competition for the best performance in standardized tests at national and international levels, searching for the best places in rankings, frequently forgetting the central importance of the individual person in the educational process. Learning content ends up becoming more important than interpersonal relations, making of schools a sterile space concerning relationships, thinking and creation. Students' performance goals have been used to measure the pedagogical work of schools and the quality of the educational process without 
taking into account social, cultural and economic specificities of both students and teachers who belong to the less privileged groups in society, who, in the case of Brazil, are, mostly, enrolled in state schools.

This type of thinking emphasizes the idea that state schools are incompetent in teaching, whereas private schools are places of good, efficient teaching. It serves to diminish the value of state schools and their communities, putting forward an atmosphere of hopelessness and failure that deepens educational and social inequality and makes it more difficult to face school problems. On the other hand, it helps create a climate favourable to projects associated with the privatization of education, central to neoliberal educational policies.

In this context, this paper addresses the following question: Instead of aiming at the first places in national and international rankings, in a tireless and blind search for being the best school or the perfect school, would it not be more desirable for a school to be just good enough? That is, a school concerned with facing its local problems, guided by the objective and subjective conditions at stake to overcome problems and issues of personal, social and global order, focusing on contributing to the development of processes of humanization, democratization, qualification and care? Is there such a school? How does it work? In which educational philosophy is it based? How is dissent voiced in the context of the complex contemporary debate? Our working hypothesis here is that such a school, at least potentially, does exist. Therefore, this article aims at developing concepts of liberating education, in association with the notion of the Good Enough School as a counterpoint to the current Brazilian educational context.

In order to build a theoretical concept of liberating education and of a good enough school in the contemporary context, we use Dussel (1977) and his Latin-American philosophy, whose ethical reasoning have, as starting points, the listening and qualification of the alterity of the Other, Freire's (1997) criticism of liberating education, Winnicott (2005a), whose original concept of "good enough mother"we adapted, and the concept of "potential space" that helps to understand the importance of a school that includes, takes care and teaches. In addition, we employ Arendt's concept of space of appearance, and from Biesta (2013), we developed the understanding of the importance of balancing concepts such as subjectification, socialization and qualification. Observing the knowledge of indigenous communities and their ways of being and acting in the world also allows us to take into account another dimension of education: transcendentalism. After building up the hypothesis of liberating education in a good enough school, the second part of the paper seeks to understand the key principles that sustain practices of liberating education.

Some important experiences have contributed to the development of the main insights of this text. Being teachers in both public and state schools enabled us to reconsider the classic and "dated" critique of schools as dualist (Establet \& Baudelot, 1971), reproductivist (Bourdieu \& Passeron, 1970) and serving the state's ideological apparatus (Althusser, 1988). The unfair Brazilian educational system keeps producing social inequality. The participation in spaces of management at both local and national levels has emphasized the urge to put schools closer to the real world and to real life: to fight neoliberal educational policies that produce maladies and teachers' and students' alienation; demoralization of public schools; the emphasis on the importance and role of teachers in the fight for privileged spaces of education not only by practising their teaching in the classroom, but also getting involved, themselves, in arenas of school governance. 


\section{Education Citizenship and Social Justice}

In the 1980s, the Brazilian education system started to adjust to market demands (Saviani, 2007). Neoliberal policies in education reinforced the dualist school (Establet \& Baudelot, 1971) and, as a consequence, the reproductivist character of education (Bourdieu \& Passeron, 1970) emerged from the ideological discourse of schooling. Practices of exclusion and unfairness increased in the country's educational system.

Considering that almost half of those students who attend Brazilian state schools come from families in situations of poverty (Duarte, 2011), state schools fulfill the important role of socialization, becoming, in some cases, the last alternative for children and adolescents who face social vulnerability. By failing to achieve for their students the practice of citizenship (involving rights such as cultural, social and political experience), state schools fail with this population, creating a vicious circle that keeps reproducing education inequality in the country. Meanwhile, rich students go to private schools and become successful.

Inequality in Brazilian schooling has been considered a major obstacle to sustainable development and to the promotion of social equity in Brazil (Brasil, 2014). The last report of the Council for Economic and Social Development (Brasil, 2014) shows that the index of unequal access and permanence in school continues, in spite of the general improvement of educational figures in Brazil in the period between 2005 and 2012. Although the distance between different social groups of the population is decreasing, the gap between the richest and the poorest parts of the populations still places Brazil amongst the most unequal countries in the world (Brasil, 2014).

Although the data from the report by the Council for Economic and Social Development (Brasil, 2014) points out that schools in Brazil are not making a difference for the poor, attributing the responsibility for school failure just to schools is as simplistic and liberal as attributing the responsibility for overcoming poverty only to the individual. In both situations, the state has the fundamental role of consolidating public policies that guarantee access to the basic rights expressed in the Brazilian Federal Constitution to the whole Brazilian population.

Duarte (2011) investigated the relationship between education and those living in situations of poverty or psychosocial risk. Her results showed that poverty, itself, explains $26 \%$ of the Brazilian school failure. Her study also identified that $44 \%$ of state school students live with less than US $\$ 18.00$ per month. The author emphasizes that when put together, all the elements of the complex educational policy (salary, career, teachers' education, organization of the pedagogical work in classroom and school, equipment, installations, teaching material, educational technology available, school management, programs, all actions associated with social policy, amongst other nonidentified factors) explain 74\% of Brazil's poor educational results (Duarte, 2011).

Besides poverty, the school institution operates with internal mechanisms of social exclusion that reflect the relationship that it maintains with diversity. Prejudice and social bias in state schools continues to be a reality, reflecting a society that shows little tolerance for differences of ethnic, gender, trans-generational, socioeconomic and territorial order. A study by Fundação Instituto de Pesquisas Econômicas (FIPE) in 2008 on diversity in Brazilian education has shown that schools with high marks in scores that measure prejudice and knowledge of prejudicial practices show lower evaluation scores in ProvaBrasil, the Brazilian test that assess school quality in basic education, than those with low scores in the same dimensions. Schools whose students show a low inclination to maintain contact with social groups historically discriminated such as black and poor

Journal of Contemporary Issues in Education, 2017, 12(1), pp. 19-31. 
people, tend to score higher in the same test (Brasil, 2009). Duarte's (2011) analysis concludes that poverty and social prejudice are strong indicators of school failure.

Since the 1990s, this context has become even more critical, considering that international institutions such as the World Bank and the Organization for Economic Cooperation and Development began to promote education policies that promised to overcome global challenges, particularly through the development of human capital and the promotion of global markets in which education would be based on competition and standardized exams. The adoption of business administration models and the search for efficiency and efficacy began to guide education policies in a way that encouraged the achievement of goals and of excellence, redefining, thus, the role to be played by the school. The redefinition by the World Trade Organization (WTO) of education as a service, and not as a right, as it is guaranteed by the Federal Constitution (1988), favoured the systematic role played by those institutions, decreasing, in this manner, the autonomy and power of nation-states. At the same time, processes of internationalization instituted the mercantilization of education and made it natural for schools, universities and entire nations to compete for the first places in international education rankings.

\section{The Good Enough School}

The concept of a Good Enough School could be one of the answers to the abuses of the Brazilian society against its youth and against its teachers and managers when pressuring them to live by the standards of meritocratic policies that require standardized models of performance, even when the necessary conditions to fully develop their work are not offered.

The concept of a Good Enough School is analogous to the concept of a Good Enough Mother (Winnicott, 2005a), which is a mother that does not have to be perfect or complete, just good enough, since her capacity for total care is the one that produces the essential place for the development of the baby's autonomy, intelligence and creativity. Winnicott (1975) argues that the role played by the mother is of great importance for the emotional development of a healthy baby, considering, above all, that a facilitating environment requires human quality more than mechanical perfection.In the same manner, a Good Enough School is not and does not have to be complete, but it must understand that the gaps that are left uncovered can be filled by the school's community, especially when it is allowed to be included in the privileged potential space of appearance, which is a space characterized by the capacities for action, communication, creation and transformation.

According to Winnicott (1962), the maternal function in the first years of a baby's life is defined by three types of care: holding (giving shelter to the baby), handling (giving the physical care that he/she needs and object presentation (showing the baby the external reality). In the initial phases of his/her development, a child that is surrounded by a good enough environment develops the capacity to care for others. This capacity is the result of complex processes of maturation that occur as a consequence of a good enough care (Winnicott, 1962).

Hence, in the absence of a good enough maternal care, the school ends up being the ultimate alternative for children as it is the institution that provides the shelter, protection and opportunities for them to be recognized by their personal singularities and their capacity to care for the Other, besides its teaching role. LaMothe (2014) has brought together the concepts of potential space (Winnicott, 1975) and space of appearance (Arendt, 2007), suggesting the importance of establishing a link between "the psychosocial space of interaction between the parent and the child, 
which becomes part of the mental life of the child, and the political space shared by citizens" (LaMothe, 2014, pp. 290-291).

Arendt (1958) brings about a definition of political space that takes into account what she considers to be the three modalities of an active life: labor, as a biological process required for the maintenance of life and the human body; work, which has to do with production, creation and instrumentality; and action, which is what makes each one of us unique, since it is the manner in which we appear to the world, bringing something that is new and unexpected to it. It is action that makes liberty possible as a public and political phenomenon: the space in which liberty is experienced and found in action (Biesta, 2013).

Arendt (2007) believes that our appearance in the world depends upon this action and needs to be followed by a discourse that is shared in the presence of others, which is something that makes her believe in plurality as a condition for human action. According to Arendt (2007), an action that is not followed by a discourse loses its revealing character, since no single individual is stripped from the capacity to utter his/her own words. This space of action and discourse is denominated "space of appearance," and it is located in the public sphere. On the other hand, labor and work are located in the private sphere. In consideration of Arendt and Winnicott's propositions, we propose that schools offer potential spaces of appearance, spaces that provide the necessary conditions for the full exercise of citizenship and democracy.

Nowadays, there is a discomfort that can be observed in Brazilian schools, largely as a result of policies that put significant pressure on students, teachers and school managers. They all submit themselves to the rules of standardized programs (Freitas, 2014), designed by authorities and consultants without the participation of the school community. In this context, the Good Enough School can be an alternative to the "ideal," perfect, unrealistic and unreachable school. It represents the stepping stone of a school that is possible, given objective structural conditions - which reality presents itself - and subjective ones - what we can do when considering the realities that are presented to us.

\section{The Concept of Liberating Education}

The discomfort in the face of an unfair Brazilian school system is present in Freire (1987), who provides possible alternatives to the oppressive issue of illiteracy. The concept of liberating education was developed by Freire (1997) as a response to the social and political challenges going on in Brazil during the 1960s, which ultimately culminated in the military dictatorship. Freire's work dealt with the liberation of liberties and, for that matter, he proposed an alternative form of education that constituted an opposition to the idea of banking education, which is, at its core, very distant from student realities, in general, and of illiterate adults, in particular. It also aimed at overcoming naive consciousness, particularly through the use of dialogical and transformative processes that would highlight the mechanisms of oppression and exploitation that needed to be challenged at the time.

Fifty years later, it is worth considering the meaning of liberating education in the current context, taking into account the issues faced by the Brazilian society as a whole, particularly in the field of education. A liberating education must, therefore, be able to overcome forms of being, thinking and acting that perpetuate inequality or prevent people from facing it critically. Guided by the ethics of liberation (Dussel, 1998), which intends to overcome the Western colonial philosophy whose ontology categorized Latin Americans as "objects" or "things" in the colonial world (Dussel, 1977),

Journal of Contemporary Issues in Education, 2017, 12(1), pp. 19-31. 
we depart from the idea that a liberating education can face the problems that come from the colonial heritage, consolidated for centuries and still in place. Since the end of the 1980s, when schools started the democratization process, and when the poorest part of the population started having access to the educational system, "unequal groups" (Arroyo, 2010, p. 1932) have been arriving at schools and have been incorporated into alienating projects. The processes that recognize those groups are expressed in specific legislations that take into account the cultural identity of Black, indigenous, disabled, countryside and Quilombola people, amongst others. The creation in 2004, in the Ministry of Education, of a specific Secretariat ${ }^{1}$ for dealing with the theme of diversity through policies geared towards those groups has driven Education Secretariats across the country to discuss specific policies dealing with the issue of diversity. The invisibility of Blacks, Indians, the LGBT community, and of disabled individuals is gradually coming to light, and the recognition of those groups in school is of fundamental importance in the promotion of processes of awareness.

The affirmative presence of those groups at school in Brazil is a cause of celebration. Any understanding of innovation in education, whose polyphony takes out the voices of those groups, is highly questionable: the "novelty" that it intends to put forth will be nothing more than a narcissistic view that perpetuates enchantments from the past.

According to Dussel (1977), listening to the voice of the Other requires a certain atheism in the system ${ }^{2}$ and the need to find one's own fetishism. When facing one's own exteriority, it is necessary to respect the Other through a position of "metaphysical passivity" that will let him/her be what he/she really is at the core. Any activity that deals with the issue of justice starts with a metaphysical attitude of respect, which does not mean a respect for the law (which is abstract and universal), neither for the system or its project, but rather to individuals who must be recognized in their own liberty, i.e., as the only entity worthy of unlimited respect. "To talk about respect is to talk about silence; not the silence of those who have nothing to say, but of those who are open to listen to everything, because they know nothing about the other as the other" (Dussel, 1977, p. 65).

To overcome a dominating system, an analectic movement, which consists of listening to the Other, is necessary. This movement integrates individuals who are considered, "a priori," unequal by their exteriority, by enabling them to feel present through the utterance of their own words, establishing, thus, a world that is indeed possible. And it is under this perspective that a liberating education can be sustained: an ethical system that denies any process of domination or colonialism that is still present in African and Latin American countries, and in Brazil, in particular.

The concept of coloniality (Quijano, 1992), one of the fundamental axes of colonization and power in the Modern era, emerged as part of a social classification of the world population according to the idea of race, a construction of the mind that expressed the idea of colonial domination and permeated some of the most important dimensions of the world, including its specific rationality: that of Eurocentrism. "This axis has, therefore, its origins in the colonial character, but has proven to be more stable and lasting than the colonialism in whose matrix it was itself established" (Quijano, 2005, p. 117), since coloniality can exist without colonialism.

The pillars of the decolonizing option are, therefore, a deconstruction of the racist and patriarchal political theory that denies the political and epistemological agency of individuals that are classified

\footnotetext{
${ }^{1}$ Department of Continuing Education, Literacy and Diversity [SECAD], now called the Secretariat of Continuing Education, Literacy, Diversity and Inclusion [SECADI].

${ }^{2}$ Dussel (1977) refers to the political, pedagogical, erotic and antifetishism systems.
} 
as inferior. This deconstruction will enable, as a consequence, the replacement of the old political theory by a new political identity. It is, however, a proposal that is very different from post-modern criticism. Although the reasoning and rationality of western authors such as Las Casas, Marx, Freud, Nietzsche are very different for not being totally imperialistic, their criticism remains attached to the rules of the game that were based on the Greek and Latin categories of the imperial reasoning (Mignolo, 2008). Thus, the decolonial option means that one needs to learn how to unlearn, and demands what Mignolo (2008) denominates an epistemic disobedience.

Any change provided by a decolonial policy (non-racist, non-heterosexual patriarchic) must raise some form of political and epistemic disobedience. Therefore, it is impossible to think about a liberating education that does not take into account processes of decolonization. The concept of liberating education as a form of mass education is stripped from any kind of alienation and it is constituted in a force for change and liberation, which means, in other words, the capacity to overcome colonized and colonizing ways of thinking. The option for a liberating education goes through, therefore, a process of decolonization that progressively allows people to break the chains that imprison them when used as objects at the service of Others (Freire, 1997).

The liberating education presumes the existence of schools that offer democratic and transcendental spaces for the creation of subjectivities, which is a concrete possibility under the positive condition of plurality. Education is not simply a process that qualifies individuals to do certain things, to have certain knowledge or skills; it is also a process that leads to the construction of socialization and subjectivity. In this sense, Biesta (2013) proposes the argument that schools must have three educational dimensions in balance: subjectification, socialization and technical qualification, all in a context of dialogue, cooperation and care.

The qualification dimension offers the acquisition of knowledge, skills, values and order. It constitutes a form of education that is geared towards the job market and represents the main focus of hegemonic education nowadays, in other words, an education that is largely influenced by the neoliberal ideology. According to Biesta (2013), the dimension of subjectification must be anchored in an ethical system that requires unconditional responsibility towards the Other. Subjectivity does not hold any type of relationship to the subject's being, but rather to his/her right to being. It is in the interruption of this "Being" that the individuality of the person acquires meaning. It is constituted in an education that leads to autonomy, to creation and innovation, and it is focused on the development of interpersonal relationships and the development of the human being. Last but not least, the socialization dimension allows us to belong to traditions and different ways of being in the world, constituting, therefore, a democratic, transformative and emancipating education based on the pillars of social justice (Biesta, 2015).

In this sense, the art of teaching means finding an appropriate balance between those three dimensions. Education, therefore, is a transformative process that must never be influenced by the individuality of personal necessities; it requires an engagement between things or individuals that are significantly different from one another. It is, in this manner, a dialogical process. This makes the path towards education lengthy, difficult and even frustrating and, for that matter, to have a type of "weakness," in the sense of flexibility, since the result of this process cannot be guaranteed nor protected (Biesta, 2013).

Biesta (2013) supports the idea of education as a risk, warning us that if we eliminate the risk of education, we run the risk of eliminating education altogether. This is exactly what Western economic forces such as the OECD and the World Bank do when pressuring nation-states to have a

Journal of Contemporary Issues in Education, 2017, 12(1), pp. 19-31.

ISSN 1718-4770 (C) 2017 University of Alberta/Centre for Global Citizenship Education and Research http://ejournals.library.ualberta.ca/index.php/JCIE 
strong, secure, predictable and "risk-free" education. They encourage a kind of perfect and unreachable form of education. Instead, the idea of imperfection is a good alternative because it provides the necessary space for movement, participation and dialectics to occur in the world. This idea is related to the importance of "weakness" in practical and educational processes, particularly with regards to the possibility that it has to open spaces for creativity, communication, learning, emancipation, democracy and virtuosity (Biesta, 2013).

Subjective processes depend fundamentally upon a specific type of relationship with the Other. Socialization is a dimension that enlivens the remaining dimensions. An ethical system must guide all of the educational process. Therefore, educational dimensions can be seen in a new light, as they relate to humanization, democratization, qualification and transcendentalism.

Humanization is the dimension that enables the school community to learn with the existence of the Other and to understand its responsibility upon him/her, by allowing him/her to talk in such a way that his/her discourse is considered as an absolute truth (Dussel, 1985). Transcendentalism, a concept that was forged on the praxis of indigenous peoples, enables us to guarantee a space in which the school community can share its lessons about caring, loving and respecting all forms of animate and inanimate beings, or even the Earth itself (Smith, 2012).The democratization dimension is defined by the space in which the school community can exert a freedom to act, speak and reflect about the challenges of politically existing in a common world (Arendt, 2007; Biesta, 2013). Finally, qualification constitutes the dimension upon which the school community can develop skills and capacities, the understanding of human relations, the connection of ideas, the strengthening of the ethical values to think, create and transform reality. This dimension has been the main focus of schools today, although they tend to focus on knowledge that is largely traditional and fragmented.

\section{The Philosophy of Liberation}

Dussel (1977) uses philosophy not only in terms of neutrality, but also as a means for liberation. He criticizes Western philosophy for being based on an ontology of the "Being" that reconstitutes the discourse of modern history by being chauvinist, dominating and racist. When reorganizing the theoretical field of Latin-American's Philosophy of Liberation, Dussel proposes an ethical philosophy that serves as a counter-discourse based on the concept of the "Other" as a possible presence in dialogue with another person. This philosophy gives a particular centrality to the category of exteriority, which indicates the realm upon which the other "being," free and unconditioned by his/her own system, and not that of the world, is revealed. In contrast, the logic of Eurocentric totality is an alienation of exteriority, an objectification of the alterity of the Other. It establishes a discourse that is based on the identity of difference; it is, in other words, the logic of totalitarianism.

The starting point of the Ethics of Liberation (Dussel, 1998) is the one that considers ethics as a form of material criticism that recognizes the dominating system. This recognition opens a new space for anti-hegemonic consensual validation based on an alterity that seeks institutional transformations or the construction of a new ethics that will constitute a process of liberation. The Philosophy of Liberation is not only restricted to critical methods (analytic philosophy, Marxism, critical theory), but it also criticizes them based on a new angle: that of global/peripheric geopolitical exteriority. It holds a constructive theoretical capacity to formulate provisory theoretical frameworks that enable us to think about urgent issues in the world of the oppressed, that is, of common people, women and the youth (Dussel, 1977). 
The Philosophy of Liberation is materialized in the recognition of the alterity of the Other in four relational moments (Dussel, 1977): the erotic, or in other words, in relationships between men and women; the pedagogical, or in the relationships between parents and their children, and between teachers and their pupils; the political, such as in the relationships between siblings and citizens; and antifetishism, or in the de-totalization of fossilized systems. The son or daughter represents a novelty, a new exteriority presented by the parents to society. When the child is born, in an erotic exteriority, he/she is educated by a family that belongs to a certain culture and social class and has a particular ethos. Later, the child will belong to a political or social pedagogical system that also belongs to a particular social ethos. Being at home or in an educational institution such as a school, there is always a threat for the denial of the alterity of the Other. This denial is manifested in the child when he or she is reduced to being a sole continuity of his or her parents, of their dreams. It also occurs when students are expected to perpetuate, repeat or mimic that which is presented to them as the only manifestation of human legacy, denying them the possibility to invent and recreate.

In both situations, education is fetishized as a tradition, eliminating, for that matter, the dialectical relationship between tradition and innovation, of politics itself. Innovation, therefore, is more than doing something that has already been done in a different way; it is, rather, making someone who was at the margins of tradition gain centrality in actions that will project him/her as an innovator. A truly innovative innovation is not the one that aims to do things differently, but rather, the one that considers doing something with those who are different.

A pedagogical liberation starts when the teacher is aware that he/she belongs to a dominating culture, which produces a mass culture that hinders the capacity for people to liberate themselves. This critical awareness is necessary for people to find the misleading realities of the system, which destroys and denies their capabilities to affirmatively construct their cultural exteriority. In the process of liberation, critical awareness is not enough, since the project of liberation is done by people, through popular forms of culture (Dussel, 1977).

When a pedagogical system is identified with an absolute reality, the ideology will reign over those who remain hidden and it will end up being interpreted as a barbarous phenomenon. This is the sanctification of pedagogical fetishism. The project of pedagogical domination is materialized in the annihilation of national cultures and oppressed social classes through the imposition of a dominating culture. Therefore, the project of pedagogical liberation is opposed to the idea of banking and alienating education. It reinforces the values of people who are at the exteriority of their popular culture (Freire, 1987).

The liberating education is geared towards overcoming the domination and alienation of intelligence, the fetishization of school as the only place for education and the resolution of social issues. It also aims at replacing the idea that teachers are the absolute masters of formal and validated knowledge; that normative grammar is the only legitimate form of use of a language and, last but not least, that the student must be idealized as an unlimited recipient of knowledge. It aims, on the other hand, to reach a praxis that is not present in the here and now, but that is guided by an unedited viable (Freire, 2003) that can establish a new school order, which is not the continuation of the current one, but rather, the recreation resulting from the revelation of the exteriority of the Other. The first concern of pedagogical liberation, according to Dussel (1977), must be the form in which a face-to-face proximity with the Other is established that in the early stages of life is represented by the proximity between the baby and the maternal lap. It is, in other words, a 
proximity that loves, cares, cherishes, secures, and humanizes. Proxemy, which results from the distance in proximity, is a fundamental experience for us to survive in the world. When the mother distances herself from the baby, he/she is put in the vicinity of things that he/she uses to satisfy some desire, or reach a goal. Things, therefore, are instruments of mediation; Others are, in this sense, a proximity that humanizes.

Those concepts hold a close relationship with Winnicott's (1975) concept of potential space, which allows for the development of the hypothesis of a Good Enough School, in the sense that it promotes proximity (accommodation) and distances (openness) that enable the subject to experience respect for alterity and self-awareness in the process of humanization. The defense of a Good Enough School is based on a collective action that opens spaces for solidarity, cooperation and democracy. According to Winnicott (2005b), family is the essential support for the constitution of the child as a person and for his or her healthy development: When contributing to the development of emotional maturity of their children, families enable them to connect with institutional and social groups. The parents' work to understand their children is the basis upon which we can predict the health and quality of a democratic society.

For the notion of the Good Enough School to work, it should be connected to the idea of liberating education as associated concepts and practices. The Good Enough School notion alone is not enough to sustain the fundamental idea of freedom, alterity, respect and emancipation that can make a difference for those historically excluded from society. It can become just another label separated from its original meaning and intentions, a simulacrum that can be appropriated by neoliberal policies and speech with focus on the individual and on education as another type of merchandizing, particularly, in the context of public-private partnerships. A Good Enough School reinforces the dimensions of care and humanization. This is particularly important for those countries that fail to guarantee those most basic rights of their populations, countries whose unequal system is clear and evident. The notion of Good Enough School alleviates the unfair charges placed on schools, freeing them to focus their educational practices on solving the many problems of school communities exposed to psychosocial risk. The Good Enough School should offer the necessary conditions for children, youth and adults to constitute themselves as persons, fully integrated citizens aware of their rights and responsibilities. It targets people who lacked these conditions during their early socialization process.

The liberating education in a good enough school is based in a material ethics whose content is human life. It expresses itself by asserting the dignity of all beings and by refusing to deny dignity to any being. Therefore, it is a decolonizing education that takes care of ways of thinking, feeling, acting and speaking. Guided by the principle of alterity, the liberating education is capable of facing and overcoming local as well as global problems. The liberating praxis is loving and dialogic. It is not concerned about being perfect or complete. There is the understanding that empty spaces are a fundamental part of education as they allow for the participation of the school community in experiences of humanization (learning to be), democratization (learning to co-exist), qualification (learning to do); and transcendentalism (learning to care). These dimensions are offered by the school in their potential spaces of appearance - spaces of care and responsibility for students and practices of politics, citizenship and democracy. It aims at building up a pleasurable school that nurtures freedom, solidarity, autonomy and is capable of encouraging the will for learning, teaching, creating and playing together in a fairer and more fraternal world. 


\section{Conclusion}

Brazil is a country still in a process of liberation from its colonial ties, which still hinders its democratic processes. Since the country was unable to reach a level of development capable of reducing social inequalities, this remains to be the main cause for family breakdowns: the lack of access to constitutional rights has a significant impact on families, making it difficult for them to exercise their role as the first institution of socialization. In this context, maternity can occur in an insufficient manner, impacting, therefore, the development of children and creating substantial problems for schools, which end up playing the role of the first socializing institution. In this sense, the Good Enough School has an important place in the lives of children and youth, since it offers, simultaneously, spaces that encourage the political exercise of citizenship.

Our notion of a liberating education in a Good Enough School is based on an ethical system guided by the principle of alterity and the capacity to overcome local and global issues, without concerning itself with being perfect or complete. It understands that empty spaces are necessary, since they allow the participation of the school community in experiences of humanization, democratization, qualification and transcendentalism, as offered in potential spaces of appearance, spaces where the capacity of caring for others and exercising one's own political citizenship occurs concomitantly. The liberating education conducted at school seeks to overcome colonialized forms of being, thinking and acting in the world; it seeks the possibility of an alternative world: more supportive, sustainable, fair and democratic. 


\section{References}

Althusser, L. P. (1998). Aparelhos ideológicos de Estado. Rio de Janeiro, RJ: Graal.

Arendt, H. (2007). Condição humana. Rio de Janeiro, RJ: Forense Universitária.

Arendt, H. (1958). The human condition. Chicago, US: University of Chicago Press.

Arroyo, M. G. (2010, Outubro/Dezembro). Políticas educacionais e desigualdades: À procura de novos significados. Educação \& Sociedade, 31(113), 1381-1416. Retrieved from http://www.scielo.br/pdf/es/v31n113/17.pdf

Biesta, G. J. (2013). The beautiful risk of education. London, UK: Paradigm Publishers.

Biesta, G. J. (2015). Redefining the basics: What really matters in education. Horsens, Denmark: University College. Retrieved from https://www.youtube.com/watch? $\mathrm{v}=\mathrm{CLcphZTGejc}$

Bourdieu, P., \& Passeron, J. C. (1970). A reprodução: Elementos para uma teoria do sistema de ensino. Lisboa, POR: Vega.

Brasil. (1988). Constituição da República Federativa do Brasil. Brasília, DF: Senado Federal. Retrieved from http://www.planalto.gov.br/ccivil_03/constituicao/Constituição.htm

Brasil. (2014). As desigualdades na escolarização no Brasil (Relatório de Observação n. 5). Brasília, DF: CDES.

Brasil, Ministério da Educação. (2009). FIPE: Projeto de Estudo sobre Ações Discriminatórias no Ambito Escolar. São Paulo, SP: INEP.

Duarte, N. S. (2011). Política educacional e o percurso escolar da população em situação de pobreza. In N. S. Duarte (Ed.). Políticas públicas e gestão da educação: construção histórica, debates contemporâneos e novas perspectivas. São Paulo: ANPAE.

Dussel, E. (1977). Filosofia da Libertação na América Latina. São Paulo: Loyola. Retrieved from http://enriquedussel.com/DVD\%20Obras\%20Enrique\%20Dussel/Textos/154/filosofia da libertacao.pdf.

Dussel, E. (1985). Philosophy of liberation. New York, NY: OrbisBooks, Maryknoll.

Dussel, E. (1998). Etica de la liberacion en la edad de la globalizacion y de la exclusion. Madrid, ES: Trotta.

Establet, R., \& Boudelot, C. (1971). L'Ecole capitaliste en France. Paris: Maspero.

Freire, P. (1987). Pedagogia do oprimido. Rio de Janeiro, RJ: Paz e Terra.

Freire, P. (1997). Educação como prática de liberdade. Rio de Janeiro, RJ: Editora Civilização Brasileira.

Freire, P. (2003). Pedagogia da Esperança: Um reencontro com a Pedagogia do Oprimido. Rio de Janeiro: Paz e Terra.

Freitas, L. C. (2014). Os reformadores empresariais da educação e a disputa pelo controle do processo pedagógico na escola. Educação \& Sociedade, 35(129), 1085-1114. https://doi.org/10.1590/ES0101-73302014143817

LaMothe, R. (2014). Winnicott and Arendt: Bridging potential and political spaces. Psychoanalytic Review, 101(2), 289-318. https://doi.org/10.1521/prev.2014.101.2.289

Mignolo, W. D. (2008). Desobediência epistêmica: a opção descolonial e o significado de identidade em política. (Cadernos de Letras da UFF-Dossiê: Literatura, língua eidentidade, n. 34). Rio de Janeiro, RJ: UFF.

Quijano, A. (1992). Colonialidad y modernidad/racionalidad. In H. Bonilla (Comp.). Los conquistados. 1492 y La población indígena de las América. Quito: Tercer MundoLibriMundiEditors.

Quijano, A. (2005). Colonialidade do poder, Eurocentrismo e América Latina. In Perspectivas latino-americanas. Buenos Aires: CLACSO. Retrieved from http://bibliotecavirtual.clacso.org.ar/clacso/sur-sur/20100624103322/12_Quijano.pdf

Journal of Contemporary Issues in Education, 2017, 12(1), pp. 19-31.

ISSN 1718-4770 (C) 2017 University of Alberta/Centre for Global Citizenship Education and Research

http://ejournals.library.ualberta.ca/index.php/JCIE 
Saviani, D. (2007). O Plano Nacional de Educação: Análise do projeto do MEC. CEDES, 28 (Especial), 1231-1255. Retrieved from http://www.cedes.unicamp.br.

Smith, L. T. (2012). Decolonizing methodologies: Research and indigenous peoples. London; New York: Zed Books.

Winnicott, D. W. (1962). El Desarrolo de la capacidad de preocuparse por elotro. In Donald Winnicott: Obras completas. Retrieved from https://ouricult.files.wordpress.com/2012/06/donald-winnicott-obras-completas.pdf. Winnicott, D. W. (1975). O brincar \& a realidade. Rio de Janeiro, RJ: Imago Editora. Winnicott, D. W. (2005a). Os bebês e suas mães. São Paulo, SP: Martins Fontes. Winnicott, D. W. (2005b). Tudo começa em casa. São Paulo, SP: Martins Fontes. 